OPEN ACCESS

Edited by:

Zaid A. Abassi,

Technion Israel Institute of

Technology, Israel

Reviewed by:

Samuel Heyman,

Hadassah Hebrew University

Hospitals, Israel

*Correspondence:

Wayne D. Comper

wcomper@hotmail.com

Specialty section:

This article was submitted to

Nephrology,

a section of the journal

Frontiers in Medicine

Received: 24 January 2022 Accepted: 07 February 2022 Published: 28 February 2022

Citation:

Comper WD (2022) Commentary: The Glomerular Endothelium Restricts

Albumin Filtration.

Front. Med. 9:861566.

doi: 10.3389/fmed.2022.861566

\section{Commentary: The Glomerular Endothelium Restricts Albumin Filtration}

\author{
Wayne D. Comper* \\ Salaqua Diagnostics Inc, New York, NY, United States
}

Keywords: charge selectivity, glomerular filtration of proteins, glomerular filtration barrier, cold isolated kidney perfusion, glycosaminoglycans

\section{A Commentary on}

The Glomerular Endothelium Restricts Albumin Filtration

by Ballermann, B. J., Nyström, J., and Haraldsson, B. (2021). Front. Med. 8:766689. doi: 10.3389/fmed.2021.766689

Contrary to the claims of Ballermann et al. (1) that "the glomerular endothelium bars the bulk of albumin from passing to the ultrafiltrate," the results from the famous physiologist/thermodynamicist AG Ogston and his colleagues at Oxford would make you argue the opposite. Ogston and Preston measured the two types of albumin interaction with glycosaminoglycan chains (the major constituent of the endothelium) including equilibrium interactions reflecting excluded volume $(2,3)$ and transport interactions representing dynamic interactions (4) under physiological conditions. Ogston et al. found both interactions quantitatively small and unremarkable and not related to charge. When considering the extracellular partitioning of albumin from the capillary into the glomerular filtrate to be of the order of 1:0.0006 then Ogston's data would be hard pressed to account for a ratio of 1:0.4 (5).

Ballermann et al. (1) also surprisingly continue to cite work from Haraldsson's group (69) on the cold isolated kidney perfusion (cIPK) technique. The technique has been discredited for some time (10) particularly in relation to apparent "charge selectivity" without the criticism being addressed. The claim of glomerular charge selectivity resides in differences in the fractional clearance of albumin and that of uncharged Ficoll of the same hydrodynamic radius of $36 \AA$. It turns out that these fractional clearance differences are near maximal at very low glomerular filtration rates (GFR) ( $<10 \%$ of normal). In fact, they routinely run their cIPKs at these low GFRs. Yet, when the operating GFR is increased to $50 \%$ normal the fractional clearance differences decrease by $90 \%$. Extrapolation to normal GFR would indicate that there are no differences at all (10). The conclusion from these studies is that the apparent "charge selectivity" is massively dependent on GFR whereas genuine charge selectivity should be completely independent of it. Clearly there are other non-charge related factors determining this GFR dependence in fractional clearance (10). Other studies by this group have utilized various enzyme and chemical treatments of the kidney to affect the charge components of the endothelium and glomerular filtration barrier as a whole but the phenomenology of these studies is hardly the basis to establish a basic force in Nature.

In terms of the biophysics of albumin transglomerular transport the conclusion, from using inert transport probes that are not metabolized by kidney cells, is that charge selectivity does 
not exist (11-14); it is a flawed concept consistent with the original observations of Ogston et al. Therefore, while the endothelium may have a very mild effect on the size exclusion of albumin, its basic role in restricting the bulk of albumin filtration has been overstated.

\section{REFERENCES}

1. Ballermann BJ, Nyström J, Haraldsson B. The glomerular endothelium restricts albumin filtration. Front Med. (2021) 8:766689. doi: 10.3389/fmed.2021.766689

2. Ogston AG, Preston BN. The exclusion of protein by hyaluronic acid. Measurement by light scattering. J Biol Chem. (1966) 241:17-9. doi: 10.1016/S0021-9258(18)96951-6

3. Shaw M, Schy A. Exclusion in hyaluronate gels. Biophys J. (1977) 17:47-55. doi: 10.1016/S0006-3495(77)85626-9

4. Ogston AG, Preston BN, Wells JD. On the transport of compact particles through solutions of chain-polymers. Proc R Soc Lond Ser A Math Phys Sci. (1973) 333:297-316. doi: 10.1098/rspa.1973.0064

5. Comper WD. The limited role of the glomerular endothelial glycocalyx as a barrier to transglomerular albumin transport. Connect Tissue Res. (2014) 55:2-7. doi: 10.3109/03008207.2013.867334

6. Ohlson M, Sörensson J, Lindström K, Blom AM, Fries E, Haraldsson B. Effects of filtration rate on the glomerular barrier and clearance of four differently shaped molecules. Am J Physiol. (2001) 281:F103-13. doi: 10.1152/ajprenal.2001.281.1.F103

7. Jeansson M, Björck K, Tenstad O, Haraldsson B. Adriamycin alters glomerular endothelium to induce proteinuria. J Am Soc Nephrol. (2009) 20:114-22. doi: 10.1681/ASN.2007111205

8. Jeansson $M$, Granqvist $A B$, Nyström JS, Haraldsson B. Functional and molecular alterations of the glomerular barrier in long-term diabetes. Diabetologia. (2006) 49:2200-9. doi: 10.1007/s00125-006-0319-z

9. Jeansson M, Haraldsson B. Morphological and functional evidence for an important role of the endothelial cell glycocalyx in the glomerular barrier. Am J Physiol Renal Physiol. (2006) 290:F111-6. doi: 10.1152/ajprenal.00173.2005

10. Comper WD, Russo LM. The glomerular filter: an imperfect barrier is required for perfect renal function. Curr Opin Nephrol Hypertens. (2009) 18:336-42. doi: 10.1097/MNH.0b013e32832cb96a

\section{AUTHOR CONTRIBUTIONS}

WDC has been instrumental over the last 25 years in examining the biophysics transglomerular transport of proteins and delineating those concepts that are relevant and experimentally validated.

11. Vyas SV, Burne MJ, Pratt LM, Comper WD. Glomerular processing of dextran sulphate. Arch Biochem Biophys. (1996) 332:205-12. doi: 10.1006/abbi.1996.0334

12. Greive KA, Nikolic-Paterson DJ, Guimarães MAM, Nikolovski J, Pratt LM, $\mathrm{Mu} \mathrm{W}$, et al. Glomerular permselectivity factors are not responsible for the increase in fractional clearance of albumin in rat glomerulonephritis. Am J Pathol. (2001) 159:1159-70. doi: 10.1016/S0002-9440(10) 61792-0

13. Guimarães MAM, Nikolovski J, Pratt LM, Greive K, Comper WD. Anomalous fractional clearance of negatively charged Ficoll relative to uncharged Ficoll. Am J Physiol. (2003) 285:F1118-24. doi: 10.1152/ajprenal. 00370.2002

14. Schaeffer RC, Gratrix ML, Mucha DR, Carbajal JM. The rat glomerular filtration barrier does not show negative charge selectivity. Microcirculation. (2002) 9:329-42. doi: 10.1038/sj.mn. 7800150

Conflict of Interest: WDC was employed by company Salaqua Diagnostics Inc.

Publisher's Note: All claims expressed in this article are solely those of the authors and do not necessarily represent those of their affiliated organizations, or those of the publisher, the editors and the reviewers. Any product that may be evaluated in this article, or claim that may be made by its manufacturer, is not guaranteed or endorsed by the publisher.

Copyright (c) 2022 Comper. This is an open-access article distributed under the terms of the Creative Commons Attribution License (CC BY). The use, distribution or reproduction in other forums is permitted, provided the original author(s) and the copyright owner(s) are credited and that the original publication in this journal is cited, in accordance with accepted academic practice. No use, distribution or reproduction is permitted which does not comply with these terms. 